\title{
Wiskott-Aldrich Syndrome Protein Family Member 3
}

National Cancer Institute

\section{Source}

National Cancer Institute. Wiskott-Aldrich Syndrome Protein Family Member 3. NCI

Thesaurus. Code C138128.

Wiskott-Aldrich syndrome protein family member 3 ( $502 \mathrm{aa}, \sim 55 \mathrm{kDa}$ ) is encoded by the human WASF3 gene. This protein plays a role in the mediation of signaling that regulates cell morphology and cytoskeletal remodeling. 